Article

\title{
Insight of Malaysian Users of Cosmetic Regarding Cosmetovigilance
}

\author{
Hazrina Hadi ${ }^{1}$, Ammar Ihsan Awadh ${ }^{2}$, Mazlina Zamli ${ }^{3}$, Nur'ain Ai ${ }^{4}$ and Shazia Jamshed ${ }^{5,6, *(1)}$ \\ 1 Department of Pharmaceuical Technology, Kulliyyah of Pharmacy, International Islamic University Malaysia, \\ Bandar Indera Mahkota, Kuantan 25200, Pahang, Malaysia; hazrina@iium.edu.my \\ 2 Department of Pharmacy, Al-Esraa University College Baghdad, Karada, Baghdad 10001, Iraq; \\ ammarehsan@yahoo.com \\ 3 Department of Pharmacy, Hospital Sultanah Nur Zahirah, Jalan Sultan Mahmud, Kuala Terengganu 20400, \\ Terengganu, Malaysia; amir.amira92@yahoo.com \\ 4 Department of Pharmacy, Hospital Wanita dan Kanak-kanak Sabah, Kota Kinabalu 88996, Sabah, Malaysia; \\ mna.nurain@gmail.com \\ 5 Department of Pharmacy Practice, Kulliyyah of Pharmacy, International Islamic University Malaysia, \\ Bandar Indera Mahkota, Kuantan 25200, Pahang, Malaysia \\ 6 Qualitative Research-Methodological Application in Health Sciences, Kulliyyah of Pharmacy, \\ International Islamic University Malaysia, Bandar Indera Mahkota, Kuantan 25200, Pahang, Malaysia \\ * Correspondence: pharmacist1992@live.com or shazia_jamshed@iium.edu.my
}

Received: 28 April 2020; Accepted: 9 June 2020; Published: 10 June 2020

check for updates

\begin{abstract}
Despite high popularity and demand for cosmetic products among users of cosmetics, there is paucity of work on cosmetovigilance. The objective of this study was to explore the cosmetovigilance-related insight encompassing the knowledge, practices, attitude, and perception of Malaysian users of cosmetics. A cross-sectional study was conducted using a structured questionnaire comprising of 47 items reflecting on demographic profile, knowledge, practices, attitude, and perception toward cosmetics. The questionnaire was administered using the SurveyMonkey website, subject to a convenience sample of 552 users of cosmetics in Malaysia. The data collected were analyzed using the Statistical Package for Social Sciences (SPSS) version 20. Insufficient knowledge of cosmetic safety was found, especially in terms of the ingredients used and the adverse effects related to common cosmetic products. The total knowledge score showed a significant difference between gender $(p<0.001)$ and monthly expenditure $(p=0.001)$. The total attitude score showed a significant difference with respect to gender $(p=0.008)$, age $(p<0.001)$, marital status $(p<0.001)$, education $(p=0.014)$, occupation $(p<0.001)$, income range $(p=0.009)$ and monthly expenditure $(p=0.013)$. The levels of cosmetovigilance-related knowledge, practices, attitude and perception of users of cosmetics in Malaysia are still unsatisfactory. The current research is expected to offer baseline data which can further help in strengthening the knowledge and attitudes of cosmetic consumers, while reinforcing best practices towards cosmetic products.
\end{abstract}

Keywords: cosmetic dermatology; cosmetic safety; cosmetovigilance; dermatopharmaceutics

\section{Introduction}

Nowadays, cosmetics are considered as a "must-have" item for people in their daily life. Cosmetic products in Malaysia are regulated by the National Pharmaceutical Regulatory Agency (NPRA) under the Control of Drugs and Cosmetics Regulations (1984). The cosmetics industry is believed to be one of the most significant industries, not only due to its role in the global Gross Domestic Product, but also to its power to influence the social life of every human being [1]. 
According to NPRA in Malaysia, a cosmetic product is "any substance or preparation intended to be placed in contact with various external parts of the human body (epidermis, hair system, nails, lips and external genital organs) or with teeth and the mucous membranes of the oral cavity, with a view exclusively or mainly to cleaning them, perfuming them, changing their appearance and/or correcting body odors and/or protecting them or keeping them in good condition".

In line with the present circumstances, a few scholars have mentioned that nowadays, consumers are looking for products that contain active ingredients and which pose significant beneficial effects $[2,3]$. In 1994, a survey was conducted by the FDA on 1687 consumers aged 14 years and older, and it was discovered that the consumers expected the effects of the product after use to be the same as what was claimed on the packaging [4]. This indicates that consumers currently have their own preferences and are more concerned about the effectiveness of the product that they intend to purchase.

Since the demand for cosmetic products is increasing, it is the basic responsibility of cosmetic companies and industries to ensure the safety of their products $[5,6]$. However, some cosmetic manufacturers are not complying to standards when it comes to the safety of their cosmetic products as they are still using prohibited substances and chemicals as ingredients in their products due to their cheap price and effectiveness, despite being aware of the possible adverse reactions that might occur $[2,7,8]$. These irresponsible manufacturers also disguise their fake cosmetic products with similar names and packaging as the original products and sell them at lower prices so as to earn high profits from the low-income consumers [9].

Recently, adverse reactions associated with the use of cosmetics have been considered as one of the crucial aspects of cosmetics [10]. Studies have been completed by other researchers to assess cosmetovigilance [10-15], and in few of these studies, consumers were the targeted participants for the studies and their responses were used substantially as references.

Cosmetic products in Malaysia are regulated under the Control of Drugs and Cosmetic Regulations (CDCR) 1984, which were promulgated under the Sale of Drugs Act 1952. In agreement with the harmonization of cosmetic through the ASEAN Cosmetic Directive (ACD), cosmetic products in Malaysia are controlled through the notification procedure that started on 1st January 2008. The CNH is required to comply with all requirements stated in this guideline and to make a declaration upon notification to the Director of Pharmaceutical Services (known as DPS) through the National Pharmaceutical Regulatory Agency (NPRA). Regulatory action will be taken in the event of false declarations and/or products found to be noncompliant to the stipulated regulations and guidelines.

Under the CDCR 1984, Regulation 18A (1): No person shall manufacture, sell, supply, import, possesses any cosmetics unless the cosmetic is a notified cosmetic. It is an offence for anyone to conduct such activities without prior notification to the DPS.

Knowledgeable and observant consumers generally update themselves through magazines, newspapers, the Internet and often receive updates and notifications from NPRA regarding recalls or cancellations of cosmetic products which have been suggested to contain harmful ingredients on information outlets such as newspapers and the Internet. Yet, there are some consumers who are not well-informed on the issues. Safety issues and problems in regard to cosmetics cannot be minimized or prevented by regulations. However, the danger towards users of cosmetics can be reduced by assessing their knowledge and attitude toward cosmetic safety and their practice and perception towards cosmetics. The data collected can also be used as a future reference for the general public, authorities, and cosmetic manufacturers. The primary aim of this study was to assess the cosmetic-related knowledge, practices, attitude, and perception of users of cosmetics in Malaysia, particularly in relation to safety and harmful effects. To be precise, a formal cosmetovigilance system is essential for the knowledge and detection of harmful ingredients and, thus, this baseline research is expected to serve an impetus in the context. 


\section{Materials and Methods}

\subsection{Development of Questionnaire}

Based on the literature review on cosmetovigilance [10,11,15-17], a set of questionnaires in English was designed and developed. There were 47 questions in the questionnaire, which was divided into five sections as follows: (a) demographic profile, (b) knowledge of cosmetic safety, (c) attitude towards cosmetic safety, (d) perception towards cosmetic, and (e) practices in relation to cosmetics. The demographic profile section consisted of 10 questions, followed by 20 questions on knowledge of cosmetic safety, 8 questions on practices in relation to cosmetics, 5 questions on attitude towards cosmetics safety, and 4 questions on perceptions toward cosmetics. The possible responses to the questionnaire were comprised of (1) "Yes", "No" and "Do not know" for the knowledge section and (2) a five-point Likert scale for the practice, attitude and perception sections. In the demographic section, the respondents were required to state their gender, age, marital status, race, location, educational background, occupation, income range, monthly expenditure on cosmetic products, and the place where they often buy their cosmetic products, by choosing one of the options provided in the questionnaire.

As outline above, the questionnaire were comprised of (1) "Yes", "No" and "Do not know" for the knowledge section but at the time of data analysis, knowledge was assessed using the following scores: ' 1 ' for a correct answer and ' 0 ' for an incorrect answer. The total knowledge score ranged from 0 to 20, with higher scores indicating a higher level of cosmetic related knowledge, which gives better and easier understanding to the reader.

\subsection{Questionnaire Translation}

The questionnaire was translated from the source language, English, into the target language, Bahasa Malaysia (the official language of Malaysia) by direct translation [18,19]. Two qualified and experienced people with a good command of English and whose mother tongue was Bahasa Malaysia were appointed to carry out the translation independently.

\subsection{Questionnaire Validation and Reliability Test}

The final version of the translated questionnaire was given to three experts. The corrections and suggestions from them were incorporated to produce the final questionnaire. On average, the respondents were able to complete the questionnaire within 5 minutes. The reliability of the questions in the knowledge, attitude, and perception sections were then analyzed using Cronbach's alpha test in the pilot study with 50 respondents. The reliability coefficient for the knowledge, attitude, and perception sections was found to be $0.75,0.71$ and 0.66 , respectively.

\subsection{Sample Size Calculation}

The total number of participants was estimated based on the Population and Housing Census of Malaysia [20]. According to Census 2010, the total population in Malaysia was 30,261,700. However, it was estimated that 19,701,100 people in Malaysia were 20 years old and above. According to the sample size formula, the sample size that was required was 383 people. The desired margin of error for this study was $5 \%$, and the $Z$ score was set at 1.96 , as this is the $Z$ score value that is appropriate for a $95 \%$ confidence level. Due to the possibility of $20 \%$ of the participants dropping out during the course of the study, the final number of participants in this study was around 500 participants. The formula used for the sample size estimation was as follows:

$$
\mathrm{ss}=\frac{\mathrm{Z}^{2} \times(\mathrm{p}) \times(1-\mathrm{p})}{\mathrm{c}^{2}}
$$

Equation of sample size formula 
ss $=$ sample size

$\mathrm{Z}=$ standard value of 1.96 (for $95 \%$ confidence level)

$\mathrm{p}=$ percentage pick of a choice (in decimals, 0.5 )

$\mathrm{c}=$ confidence interval, (in decimals, $0.05= \pm 5 \%$ )

\subsection{Ethical Consideration}

Ethical approval was obtained from the IIUM Research Ethics Committee (IREC) with a registration number of IREC587.

\subsection{Data Collection}

A cross-sectional study design was applied to assess the cosmetovigilance-related knowledge, practices, attitude, and perception of users of cosmetics in Malaysia. The questionnaire was provided in both Malaysia and English language.

The developed questionnaire was then constructed in the SurveyMonkey web link collector before being distributed to most social networks, mainly Facebook and WhatsApp Messenger using the snowball sampling method. The link for the online survey was also sent to those respondents who agreed to participate via e-mail.

The snowball sampling method was used in this study by using networks to select the sample [21]. In this study, the social networks of the authors were used. An invitation to participate in the study was sent to authors' friends circle and the friends were asked also to share or spread the questionnaire to their friends using their virtual networks. In order to avoid any replication in the participants' response, a notice was given in the invitation about not repeating the questionnaire. This sampling method was able to reduce the time and cost required to collect the required number of respondents and to expand the geographical scope [21-23].

To be eligible to participate in this study, certain criteria had to be fulfilled by the participants, namely, they had to be (1) consumers who were using cosmetic products, (2) aged 20 years old and above, (3) able to understand and write in Malay or English, and (4) residents in Malaysia.

\subsection{Data Analysis}

The data collected in this study were tabulated and analyzed using the Statistical Package for Social Sciences (SPSS) version 20. Descriptive statistic was conducted to analyze the demographic data. The knowledge was assessed using the following scores: ' 1 ' for a correct answer and ' 0 ' for an incorrect answer. The total knowledge score ranged from 0 to 20, with higher scores indicating a higher level of cosmetovigilance-related knowledge. In terms of the responses of the respondents to the attitude, perception, and practice parts, the highest score of five (5) marks was given to the right answer, followed by four (4) marks, three (3) marks, two (2) marks and one (1) mark in the order of the options on the Likert scale. The Mann-Whitney U test and a Kruskal-Wallis test were employed to determine the statistical significance of the relationship between each knowledge score, attitude score, and perception score and the demographic variables. A value of $p<0.05$ was considered significant.

\section{Results}

\subsection{Sociodemographic Characteristics of Respondents}

The sociodemographic characteristics of the respondents are listed in Table 1 . The majority of the respondents were Malay females aged between 20-29 years, single, students, and staying in urban areas $(95.7 \%, 80.6 \%, 84.8 \%, 79.0 \%, 65.8 \%$, and $81.0 \%$ respectively) In addition, most of the respondents (68.5\%) were receiving a monthly income of less than RM 2000 and $75.9 \%$ spent less than RM 100 on cosmetic products. About $76.3 \%$ of the respondents had received a higher education. The results also showed that about half of the users of cosmetics (56.3\%) bought cosmetic products at appointed stores in malls. For the detailed results, refer to Table 1. 
Table 1. Sociodemographic characteristics of respondents.

\begin{tabular}{|c|c|}
\hline Variables & $\mathbf{N}(\%)$ \\
\hline \multicolumn{2}{|l|}{ Gender } \\
\hline Male & $107(19.4)$ \\
\hline Female & $445(80.6)$ \\
\hline \multicolumn{2}{|l|}{ Age } \\
\hline $20-29$ & $468(84.8)$ \\
\hline $30-39$ & $62(11.2)$ \\
\hline $40-49$ & $14(2.5)$ \\
\hline $50-59$ & $8(1.4)$ \\
\hline \multicolumn{2}{|l|}{ Marital Status } \\
\hline Single & $436(79.0)$ \\
\hline Married & $116(21.0)$ \\
\hline \multicolumn{2}{|l|}{ Race } \\
\hline Malay & $528(95.7)$ \\
\hline Chinese & $13(2.4)$ \\
\hline Others & $11(2.0)$ \\
\hline \multicolumn{2}{|l|}{ Location } \\
\hline Urban & $447(81.0)$ \\
\hline Rural & $105(19.0)$ \\
\hline \multicolumn{2}{|l|}{ Education Background } \\
\hline SPM and below & $53(9.6)$ \\
\hline STPM/STAM and Diploma & $78(14.1)$ \\
\hline Degree/Master & $406(73.6)$ \\
\hline $\mathrm{PhD}$ & $15(2.7)$ \\
\hline \multicolumn{2}{|l|}{ Occupation } \\
\hline Not working & $16(2.9)$ \\
\hline Student & $363(65.8)$ \\
\hline Private Sector & $58(10.5)$ \\
\hline Government Sector & $115(20.8)$ \\
\hline \multicolumn{2}{|l|}{ Income range } \\
\hline Less than RM2000 & $378(68.5)$ \\
\hline RM2000-RM3000 & $72(13.0)$ \\
\hline RM3001-RM6000 & $71(12.9)$ \\
\hline RM6001-RM9000 & $21(3.8)$ \\
\hline RM9001 and above & $10(1.8)$ \\
\hline \multicolumn{2}{|l|}{ Monthly Expenditure } \\
\hline Less than RM100 & $419(75.9)$ \\
\hline RM100-RM200 & $102(18.5)$ \\
\hline RM201-RM300 & $18(3.3)$ \\
\hline RM301-RM400 & $8(1.4)$ \\
\hline RM401 and above & $5(0.9)$ \\
\hline \multicolumn{2}{|l|}{ Place to buy cosmetic products } \\
\hline The Internet & $35(6.3)$ \\
\hline Appointed store in mall & $311(56.3)$ \\
\hline Pharmacy & $185(33.5)$ \\
\hline Others & $21(3.8)$ \\
\hline
\end{tabular}

\subsection{Knowledge of Cosmetic Safety}

From Table 2, the mean \pm standard deviation for the total knowledge score was $12.5 \pm 4.0$ and the median was 13.0. The respondents had poor knowledge of cosmetic safety, especially concerning the ingredients used in cosmetic products and the adverse effects of several common cosmetic products. Although most of the respondents agreed that not all natural or organic cosmetics are risk free 
$(81 \% ; n=447)$ and may be toxic $(63.2 \% ; n=349)$, many of them did not know about lead in lipstick, parabens, and the potential adverse effects of underarm cosmetics, eye cosmetics, hair dyes, soap, bath foams, and especially, black henna (hair dye). Surprisingly, about $77.2 \%(n=426)$ of the respondents did not know that the FDA (US Food and Drug Administration) has no authority to require companies to test the safety of a product first, even though the majority of them $(92.9 \% ; n=513)$ correctly identified cosmetic regulations as being important, and many of them had good knowledge about cosmetic regulations. For the detailed results, refer to Table 3. Remarkably, a statistical difference was found between the total knowledge score and two parts of the demographic profile, namely, the gender $(p<0.001)$ and monthly expenditure $(p=0.001)$ of the respondents. For the detailed results, refer to Table 4 .

Table 2. Mean, standard deviation, median, minimum, and maximum for knowledge score, attitude score, and perception score.

\begin{tabular}{cccccc}
\hline Scores & Mean & Standard Deviation & Median & Min & Max \\
\hline Knowledge score & 12.5 & 4.0 & 13.0 & 0.0 & 20.0 \\
Attitude score & 16.8 & 3.0 & 17.0 & 8.0 & 20.0 \\
Perception score & 14.0 & 2.3 & 14.0 & 8.0 & 20.0 \\
\hline
\end{tabular}

Table 3. Response of participants to the questions on knowledge of cosmetic safety.

\begin{tabular}{|c|c|c|}
\hline Knowledge & Correct $(\%)$ & Incorrect $(\%)$ \\
\hline $\begin{array}{l}\text { Not all natural or organic cosmetics are risk free because } \\
\text { some of them are still synthetic chemicals. }\end{array}$ & $447(81.0)$ & $105(19.0)$ \\
\hline There are certain amounts of lead in lipstick. & $298(54.0)$ & $254(46.0)$ \\
\hline $\begin{array}{l}\text { Organic ingredients contained in cosmetic products may } \\
\text { be toxic or allergenic. }\end{array}$ & $349(63.2)$ & $203(36.8)$ \\
\hline $\begin{array}{l}\text { Paraben is most widely used preservative in } \\
\text { cosmetic products. }\end{array}$ & $307(55.6)$ & $245(44.4)$ \\
\hline Parabens can penetrate the skin. & $256(46.4)$ & $296(53.6)$ \\
\hline $\begin{array}{l}\text { Underarms cosmetics (e.g., deodorant) is a possible } \\
\text { cause of breast cancer due to its chemical ingredient } \\
\text { being directly applied to the area adjacent to the breast. }\end{array}$ & $284(51.4)$ & $268(48.6)$ \\
\hline $\begin{array}{c}\text { Some products can be intended as both cosmetics } \\
\text { and drugs. }\end{array}$ & $414(75.0)$ & $138(25.0)$ \\
\hline $\begin{array}{l}\text { Soap and bath foam are the main cause of allergic } \\
\text { dermatitis as the adverse cosmetic event occurs due to } \\
\text { their ingredients. }\end{array}$ & $299(54.2)$ & $253(46.8)$ \\
\hline $\begin{array}{l}\text { Cosmetics should not be used in areas affected by } \\
\text { infections or inflammation. }\end{array}$ & $474(85.9)$ & $78(14.1)$ \\
\hline $\begin{array}{l}\text { Eye cosmetics like eyeliner should not be shared (e.g., the } \\
\text { tester at the shop) to different people because it will } \\
\text { spread germs. }\end{array}$ & $308(55.8)$ & $244(44.2)$ \\
\hline $\begin{array}{l}\text { Adverse cosmetic effects of hair dyes include itching, } \\
\text { burning, redness on the head and swelling on the face. }\end{array}$ & $248(44.9)$ & $304(55.1)$ \\
\hline Black henna can cause allergic reactions to the skin. & $161(29.2)$ & $391(70.8)$ \\
\hline $\begin{array}{l}\text { The most common adverse cosmetic events and } \\
\text { intolerance are irritation, a burning sensation, light } \\
\text { itching in correspondence to applied zone of } \\
\text { the cosmetic. }\end{array}$ & $458(83.0)$ & $94(17.0)$ \\
\hline $\begin{array}{l}\text { Counterfeit/fake cosmetic products can cause negative } \\
\text { side effect to users. }\end{array}$ & $494(89.5)$ & $58(10.5)$ \\
\hline $\begin{array}{l}\text { The effectiveness of counterfeit/fake cosmetic products is } \\
\text { similar to the original products. }\end{array}$ & $366(66.3)$ & $186(33.7)$ \\
\hline $\begin{array}{l}\text { FDA (U.S Food and Drug Administration) has no } \\
\text { authority to require companies to test products safety } \\
\text { before launching them. }\end{array}$ & $126(22.8)$ & $426(77.2)$ \\
\hline It is important to have regulation for cosmetic products. & $513(92.9)$ & $39(7.1)$ \\
\hline $\begin{array}{l}\text { National Pharmaceutical Control Bureau is responsible } \\
\text { for governing the regulation of cosmetic products. }\end{array}$ & $435(78.8)$ & $117(21.2)$ \\
\hline $\begin{array}{c}\text { The list of cosmetic products that has been withdrawn } \\
\text { from the market can be searched in the National } \\
\text { Pharmaceutical Control Bureau website. }\end{array}$ & $311(56.3)$ & $241(43.7)$ \\
\hline $\begin{array}{l}\text { Any cosmetic adverse event can be reported to the } \\
\text { National Pharmaceutical Control Bureau. }\end{array}$ & $361(65.4)$ & 191 (34.6) \\
\hline
\end{tabular}


Table 4. Total knowledge score differences.

\begin{tabular}{|c|c|c|c|c|}
\hline Variables & N (\%) & Mean & Median & $p$ Value \\
\hline Gender & & & & $<0.001$ \\
\hline Male & $107(19.4)$ & 10.5 & 11.0 & \\
\hline Female & $445(80.6)$ & 13.0 & 13.0 & \\
\hline Age & & & & 0.954 \\
\hline $20-29$ & $468(84.8)$ & 12.5 & 13.0 & \\
\hline 30-39 & $62(11.2)$ & 12.6 & 12.5 & \\
\hline $40-49$ & $14(2.5)$ & 13.3 & 13.0 & \\
\hline $50-59$ & $8(1.4)$ & 12.5 & 13.0 & \\
\hline Marital Status & & & & 0.903 \\
\hline Single & $436(79.0)$ & 12.5 & 13.0 & \\
\hline Married & $116(21.0)$ & 12.5 & 13.0 & \\
\hline Race & & & & 0.812 \\
\hline Malay & $528(95.7)$ & 12.5 & 13.0 & \\
\hline Chinese & $13(2.4)$ & 12.7 & 12.0 & \\
\hline Others & $11(2.0)$ & 13.3 & 14.0 & \\
\hline Location & & & & 0.622 \\
\hline Urban & $447(81.0)$ & 12.5 & 13.0 & \\
\hline Rural & $105(19.0)$ & 12.6 & 13.0 & \\
\hline Education Background & & & & 0.262 \\
\hline SPM and below & $53(9.6)$ & 11.7 & 12.0 & \\
\hline STPM/STAM and Diploma & $78(14.1)$ & 12.4 & 13.0 & \\
\hline Degree/Master & $406(73.6)$ & 12.6 & 13.0 & \\
\hline $\mathrm{PhD}$ & $15(2.7)$ & 13.8 & 13.0 & \\
\hline Occupation & & & & 0.043 \\
\hline Not working & $16(2.9)$ & 11.8 & 12.0 & \\
\hline Student & $363(65.8)$ & 12.5 & 13.0 & \\
\hline Private Sector & $58(10.5)$ & 11.4 & 12.0 & \\
\hline Government Sector & $115(20.8)$ & 13.2 & 14.0 & \\
\hline Income range & & & & 0.577 \\
\hline Less than RM2000 & $378(68.5)$ & 12.4 & 13.0 & \\
\hline RM2000-RM3000 & $72(13.0)$ & 12.5 & 13.0 & \\
\hline RM3001-RM6000 & $71(12.9)$ & 12.9 & 14.0 & \\
\hline RM6001-RM9000 & $21(3.8)$ & 13.0 & 14.0 & \\
\hline RM9001 and above & $10(1.8)$ & 11.7 & 13.0 & \\
\hline Monthly Expenditure & & & & 0.001 \\
\hline Less than RM100 & $419(75.9)$ & 12.1 & 12.0 & \\
\hline RM100-RM200 & $102(18.5)$ & 13.7 & 14.0 & \\
\hline RM201-RM300 & $18(3.3)$ & 14.4 & 16.0 & \\
\hline RM301-RM400 & $8(1.4)$ & 14.0 & 14.5 & \\
\hline RM401 and above & $5(0.9)$ & 11.4 & 12.0 & \\
\hline Place to buy cosmetic products & & & & 0.006 \\
\hline The Internet & $35(6.3)$ & 11.4 & 13.0 & \\
\hline Appointed store in mall & $311(56.3)$ & 12.5 & 13.0 & \\
\hline Pharmacy & $185(33.5)$ & 13.1 & 13.0 & \\
\hline Others & $21(3.8)$ & 10.1 & 10.0 & \\
\hline
\end{tabular}

\subsection{Attitude towards Cosmetic Safety}

A large number of respondents $(341 ; 61.8 \%)$ strongly agreed and agreed with the statement, "I never buy any new cosmetic product without knowing anything regarding the ingredients". In addition, $67.6 \%(n=373)$ of the respondents strongly agreed and agreed with the statement, "I always check the expiry date before purchasing cosmetic products". However, $41.1 \%(n=227)$ of them did not have an opinion regarding the following statement, "I purchase natural beauty products more frequently than conventional beauty products" as their response was "neutral". Moreover, 37.7\% ( $n=208)$ of the respondents disagreed with the statement, "I always check the list of cosmetic products that have been removed by the authorities". One fourth of the respondents $(21.7 \%)$ strongly agreed with the statement, "I agree that the notification number for cosmetic products starts with the code MAL", which was wrong, as the notification number starts with the code NOT. The total attitude score showed a statistically significant difference with respect to the gender $(p=0.008)$, age $(p<0.001)$, marital 
status $(p<0.001)$, education $(p=0.014)$, occupation $(p<0.001)$, income range $(p=0.009)$ and monthly expenditure $(p=0.013)$. For the detailed results, refer to Table 5; Table 6.

Table 5. Response of participants to the questions on attitude towards cosmetic safety.

\begin{tabular}{|c|c|c|c|c|c|}
\hline Items & Strongly Disagree (\%) & Disagree (\%) & Neutral (\%) & Agree (\%) & Strongly Agree (\%) \\
\hline $\begin{array}{l}\text { I never buy any new cosmetic products without } \\
\text { knowing anything regarding the ingredients. }\end{array}$ & $14(2.5)$ & $42(7.6)$ & $155(28.1)$ & $170(30.8)$ & $171(31.0)$ \\
\hline $\begin{array}{l}\text { I purchase natural beauty product more } \\
\text { frequently than conventional beauty products. }\end{array}$ & $33(6.0)$ & $69(12.5)$ & $227(41.1)$ & $128(23.2)$ & $95(17.2)$ \\
\hline $\begin{array}{l}\text { I always check the expiry date before } \\
\text { purchasing cosmetic products. }\end{array}$ & $13(2.4)$ & $55(10.0)$ & $111(20.1)$ & $151(27.4)$ & $222(40.2)$ \\
\hline $\begin{array}{l}\text { I always check the list of cosmetic products that } \\
\text { have been removed by the authorities. }\end{array}$ & $78(14.1)$ & $130(23.6)$ & 169 (30.6) & $96(17.4)$ & 79 (14.3) \\
\hline $\begin{array}{l}\text { I agree that the notification number for } \\
\text { cosmetic products starts with the code MAL. }\end{array}$ & $81(14.7)$ & $47(8.5)$ & $207(37.5)$ & $97(17.6)$ & $120(21.7)$ \\
\hline
\end{tabular}

Table 6. Total attitude score differences.

\begin{tabular}{|c|c|c|c|c|}
\hline Variables & N (\%) & Mean & Median & $p$ Value \\
\hline Gender & & & & 0.008 \\
\hline Male & $107(19.4)$ & 16.2 & 16.0 & \\
\hline Female & $445(80.6)$ & 16.9 & 17.0 & \\
\hline Age & & & & $<0.001$ \\
\hline $20-29$ & $468(84.8)$ & 16.6 & 17.0 & \\
\hline $30-39$ & $62(11.2)$ & 17.6 & 18.0 & \\
\hline $40-49$ & $14(2.5)$ & 18.6 & 19.0 & \\
\hline $50-59$ & $8(1.4)$ & 19.0 & 20.0 & \\
\hline Marital Status & & & & $<0.001$ \\
\hline Single & $436(79.0)$ & 16.5 & 16.5 & \\
\hline Married & $116(21.0)$ & 17.8 & 18.0 & \\
\hline Race & & & & 0.071 \\
\hline Malay & $528(95.7)$ & 16.7 & 17.0 & \\
\hline Chinese & $13(2.4)$ & 18.4 & 18.0 & \\
\hline Others & $11(2.0)$ & 16.8 & 17.0 & \\
\hline Location & & & & 0.886 \\
\hline Urban & $447(81.0)$ & 16.8 & 17.0 & \\
\hline Rural & $105(19.0)$ & 16.8 & 17.0 & \\
\hline Education Background & & & & 0.014 \\
\hline SPM and below & $53(9.6)$ & 17.6 & 17.0 & \\
\hline STPM/STAM and Diploma & $78(14.1)$ & 17.4 & 18.0 & \\
\hline Degree/Master & $406(73.6)$ & 16.5 & 17.0 & \\
\hline $\mathrm{PhD}$ & $15(2.7)$ & 16.8 & 16.0 & \\
\hline Occupation & & & & $<0.001$ \\
\hline Not working & $16(2.9)$ & 17.7 & 18.5 & \\
\hline Student & $363(65.8)$ & 16.4 & 16.0 & \\
\hline Private Sector & $58(10.5)$ & 16.6 & 16.5 & \\
\hline Government Sector & $115(20.8)$ & 18.0 & 18.0 & \\
\hline Income range & & & & 0.009 \\
\hline Less than RM2000 & $378(68.5)$ & 16.5 & 17.0 & \\
\hline RM2000-RM3000 & $72(13.0)$ & 17.5 & 17.0 & \\
\hline RM3001-RM6000 & $71(12.9)$ & 17.2 & 18.0 & \\
\hline RM6001-RM9000 & $21(3.8)$ & 17.1 & 17.0 & \\
\hline RM9001 and above & $10(1.8)$ & 18.6 & 19.0 & \\
\hline Monthly Expenditure & & & & 0.013 \\
\hline Less than RM100 & 419 (75.9) & 16.6 & 17.0 & \\
\hline RM100-RM200 & $102(18.5)$ & 17.3 & 17.0 & \\
\hline RM201-RM300 & $18(3.3)$ & 18.5 & 18.5 & \\
\hline RM301-RM400 & $8(1.4)$ & 15.1 & 15.0 & \\
\hline RM401 and above & $5(0.9)$ & 15.8 & 15.0 & \\
\hline Place to buy cosmetic products & & & & 0.693 \\
\hline The Internet & $35(6.3)$ & 17.0 & 17.0 & \\
\hline Appointed store in mall & $311(56.3)$ & 16.7 & 17.0 & \\
\hline Pharmacy & $185(33.5)$ & 16.8 & 17.0 & \\
\hline Others & $21(3.8)$ & 17.2 & 18.0 & \\
\hline
\end{tabular}

\subsection{Perceptions toward Cosmetic Roducts}

As reported in Table 2, the mean \pm standard deviation for the total perception score was $14.0 \pm 2.3$ and the median was 14.0 . Slightly more than half of the respondents $(58.1 \% ; n=321)$ had a positive perception that the price of cosmetic products did not indicate its efficacy; slightly more than one fourth 
felt that cosmetic products speed up skin aging $(30.0 \% ; \mathrm{n}=166)$; slightly more than half reported that they cause acne $(58.5 \% ; n=323)$; slightly less than half reported that at least one ingredient is toxic to the human body $(48.9 \% ; n=270)$. The detailed results are shown in Table 7 . There was no significant difference between the total perception score and the respondents' sociodemographic characteristics.

Table 7. Response of participants to the questions on perception towards cosmetic.

\begin{tabular}{cccccc}
\hline Items & Strongly Disagree (\%) & Disagree (\%) & Neutral (\%) & Agree (\%) & Strongly Agree (\%) \\
\hline $\begin{array}{c}\text { The price of the cosmetic products did } \\
\text { not indicate its efficacy. }\end{array}$ & $8(1.4)$ & $64(11.6)$ & $159(28.8)$ & $194(35.1)$ & $127(23.0)$ \\
Cosmetics speed up skin aging. & $15(2.7)$ & $80(14.5)$ & $291(52.7)$ & $126(22.8)$ & $40(7.2)$ \\
$\quad \begin{array}{c}\text { Cosmetics can cause acne. } \\
\text { Cosmetic products have at least one }\end{array}$ & $5(0.9)$ & $40(7.2)$ & $184(33.3)$ & $237(42.9)$ & $86(15.6)$ \\
toxic ingredient to human body. & $6(1.1)$ & $40(7.2)$ & $236(42.8)$ & $194(35.1)$ & $76(13.8)$ \\
\hline
\end{tabular}

\subsection{Practices toward Cosmetic Products}

Overall, the majority reported good practices towards cosmetic products. Despite the fact that the occasional cleaning of cosmetic equipment after use was practiced by the highest proportion of respondents (35.7\%; $n=197)$, the grouping of respondents who often and always cleaned their cosmetic equipment after use constituted 39.5\% $(n=218)$, exceeding the frequency of occasional use. More than three-quarters of the respondents $(72.8 \% ; n=402)$ answered "often" and "always" in terms of keeping their cosmetic products in proper storage before and after use. Most of them also did not apply cosmetic products more than the required number of times per day, as 38.8\% ( $=214)$ of them answered "never" and $34.6 \%(n=191)$ answered "rarely". More than half of the respondents $(61.1 \% ; n=337)$ never used similar cosmetic products on other parts of the body when adverse cosmetic events occurred. In addition, $54.2 \%(n=299)$ of the respondents always buy their cosmetic products from authorized dealers/sellers. Nearly three-quarters $(68.5 \% ; n=378)$ of the respondents never applied their cosmetic products on cuts and abrasions, while $24.1 \%(n=133)$ and $21.4 \%(n=118)$ of the respondents selected "never" and "rarely" as their response, respectively, when they were asked whether they bought a lot of cosmetic products but rarely used them, thus constituting $45.5 \%(n=251)$ overall. For the detailed results, refer to Table 8 .

Table 8. Response of participants to the questions on practices towards cosmetics.

\begin{tabular}{|c|c|c|c|c|c|}
\hline Items & $\begin{array}{l}\text { Never } \\
(\%)\end{array}$ & $\begin{array}{c}\text { Rarely } \\
(\%)\end{array}$ & $\begin{array}{l}\text { Sometimes } \\
(\%)\end{array}$ & $\begin{array}{c}\text { Often } \\
(\%)\end{array}$ & $\begin{array}{l}\text { Always } \\
(\%)\end{array}$ \\
\hline I clean cosmetic equipment after use. & $42(7.6)$ & $95(17.2)$ & $197(35.7)$ & $110(19.9)$ & $108(19.6)$ \\
\hline I keep cosmetic products in proper storage before and after use. & $12(2.2)$ & $47(8.5)$ & $91(16.5)$ & $184(33.3)$ & $218(39.5)$ \\
\hline I apply cosmetic products more than the required number per day. & $214(38.8)$ & $191(34.6)$ & $94(17.0)$ & $32(5.8)$ & $21(3.8)$ \\
\hline $\begin{array}{l}\text { I use similar cosmetic products on other parts of body when adverse } \\
\text { cosmetic events occur. }\end{array}$ & $337(61.1)$ & $95(17.2)$ & 59 (10.7) & $31(5.6)$ & $30(5.4)$ \\
\hline I apply cosmetic products on cuts and abrasions. & $378(68.5)$ & $77(13.9)$ & $68(12.3)$ & $18(3.3)$ & $11(2.0)$ \\
\hline
\end{tabular}

\section{Discussion}

The results indicate that gender and monthly expenditure significantly influence knowledge of cosmetic safety. The results show that females are more knowledgeable of cosmetic safety compared to males (mean $=13.0$ vs. 10.5, respectively). This is possible as females are more concerned about their beauty compared to males, as they spend more money on the monthly purchase of cosmetic products ( $26.7 \%$ females vs. $17.8 \%$ males, respectively). This is supported by a recent study in Delhi that found that most female users of cosmetics try to enhance their physical looks by using cosmetic products, as they feel that their physical looks are vital [16]. Moreover, according to Etcoff [24], more than 80\% of women over the age of 18 years wear cosmetics.

Insufficient knowledge of cosmetic safety was found, especially of the ingredients used in cosmetic products and the adverse effects of several common cosmetic products. Many studies have revealed 
that cosmetic products such as lipsticks, deodorants, eye cosmetics, soaps, bath foams, and black henna (hair dye) are the most frequent causes of contact allergies and other undesirable effects [11,25-30]. This is a cause for concern as these cosmetic products are being widely used by consumers who do not have knowledge regarding the ingredients. Certain users of cosmetics prefer to just randomly buy cosmetic products without knowing the usefulness and negative side effects of the items [31]. As such, these users of cosmetics underestimate the potential adverse effects that are associated with cosmetic products. This result is in line with that of a previous study [32], which showed that mild to moderate adverse effects are often taken lightly by users of cosmetics who commonly self-diagnose and self-medicate.

The total attitude score was influenced by various factors (gender, age, marital status, education, occupation, income range, and monthly expenditure). Users of cosmetics should be educated on cosmetic safety, particularly, by means of a notifications system by the NPRA. They should also be encouraged to check the list of cosmetic products that have been removed by the authorities on the NPRA website, as most of these products have been adulterated with scheduled poisons such as mercury, hydroquinone, tretinoin, azelaic acid and others which can lead to severe adverse cosmetic events. These matters are very crucial as they can help to decrease the occurrence of adverse cosmetic events and improve the effectiveness of a post-market surveillance system. Mansor et al. [31] and Siti Zulaikha et al. [33] agree with this, as they also believe that users of cosmetics must be aware of the cosmetic products they are using and keep themselves updated with knowledge regardless of the fact that there are regulations to control them. Not only that, many scholars have also emphasized the implementation of a cosmetovigilance system to investigate information on the safety of consumer ingredients through collaboration among different scientific experts, health authorities, industries/manufacturers and consumer organizations in an attempt to avoid the risk of adverse effects on users of cosmetics [10,11,24,25].

Most of the respondents negatively perceived that cosmetic products cause acne and have at least one toxic ingredient. This was possibly due to a lack of knowledge and the attitude among the respondents, as previously mentioned. It might also have been due some of them having experiences with at least one adverse cosmetic event in the past, or being influenced by the people around them who had experienced adverse cosmetic events. This can be explained by a study which showed that Asian skin is the most sensitive skin when compared with Caucasian and Black skin [34], probably due to the weak strength of the skin barrier properties which leads to incomplete maturation of the skin [35]. This high skin sensitivity has been associated with an increased tendency to suffer adverse reactions from cosmetics and toiletries [36].

Moreover, in terms of practices toward cosmetic products, the proportion of respondents that applied proper practices can still be further improved. It is strongly recommended that education in up-to-date cosmetics practices, techniques, and effective applications should be introduced so that cosmetic products can be utilized to the maximum and effectively [37]. Hence, the attractiveness of the outer appearance of users of cosmetics can be enhanced dramatically, and their perception towards cosmetic products can be positively improved indirectly.

There were some limitations to the current research. Although the sample group was sufficient for s drawing inferences, it still represented only a small portion of Malaysian cosmetics users. Moreover, participants were selected using a combination of convenience and snowball sampling. The majority of the participants were students, which may limit the generalizability of the study. Future investigation using probability sampling methods and a larger sample group would provide a better representation of the population. Therefore, the findings need to be interpreted within the context of the study's limitations.

\section{Conclusions}

The results of this study have demonstrated the low level of knowledge of and attitude toward cosmetic safety among consumers of cosmetics in Malaysia. The respondents had a high level of 
practice and a negative perception toward cosmetic products. The findings of the current research are expected to inform the authorities and nongovernmental organizations of the need to increase the awareness and knowledge of cosmetic consumers regarding cosmetic safety.

Author Contributions: Conceptualization, H.H. and A.I.A.; methodology, H.H. and A.I.A.; software, N.A.; validation, A.I.A., S.J. and N.A.; formal analysis, M.Z.; investigation, M.Z.; resources, N.A.; data curation, N.A., M.Z.; writing—original, N.A., M.Z.; writing-S.J., H.H., A.I.A.; visualization, H.H.; supervision, H.H., S.J.; project administration, H.H. All authors have read and agreed to the published version of the manuscript.

Funding: This research received no external funding.

Acknowledgments: In this section you can acknowledge any support given which is not covered by the author contribution or funding sections. This may include administrative and technical support, or donations in kind (e.g., materials used for experiments).

Conflicts of Interest: The authors declare no conflict of interest.

\section{References}

1. Available online: https:/www.npra.gov.my/images/Guidelines_Central/Guidelines_on_Cosmetic/2017/ feb2020GUIDELINES_FOR_CONTROL_OF_COSMETIC_PRODUCTS_IN_MALAYSIA.pdf (accessed on 12 May 2020).

2. Hutt, P.B. The legal distinction in the United States between a cosmetic and a drug. J. Toxicol. Cutan. Ocul. Toxicol. 2001, 20, 203-219. [CrossRef]

3. Kligman, A. Cosmeceuticals: A Broad-Spectrum Category between Cosmetics and Drugs. In Cosmeceuticals and Active Cosmetics Drug versus Cosmetics; Taylor \& Francis Group: Boca Raton, FL, USA, 2005; pp. 1-9.

4. Lewis, C. Clearing up cosmetic confusion. FDA Consum. 1998, 32, 6-11. [PubMed]

5. Ross, G. A perspective on the safety of cosmetic products: A position paper of the American Council on Science and Health. Int. J. Toxicol. 2006, 25, 269-277. [CrossRef] [PubMed]

6. Page, J.A.; Blackburn, K.A. Behind the looking glass: Administrative, legislative and private approaches to cosmetic safety substantiation. UCLA Law Rev. 1976, 24, 795-837.

7. Olumide, Y.M.; Akinkugbe, A.O.; Altraide, D.; Mohammed, T.; Ahamefule, N.; Ayanlowo, S.; Onyekonwu, C.; Essen, N. Complications of chronic use of skin lightening cosmetics. Int. J. Dermatol. 2008, 47, 344-353. [CrossRef] [PubMed]

8. Kligman, A. Cosmeceuticals: Do We Need a New Category? In Cosmeceuticals: Drugs vs Cosmetics; Marcel Dekker: New York, NY, USA, 2000; pp. 1-8.

9. Haque, A.; Khatibi, A.; Rahman, S. Factors influencing buying behavior of piracy products and its impact to Malaysian market. Int. Rev. Bus. Res. Pap. 2009, 5, 383-401.

10. Di Giovanni, C.; Arcoraci, V.; Gambardella, L.; Sautebin, L. Cosmetovigilance survey: Are cosmetics considered safe by consumers. Pharmacol. Res. 2006, 53, 16-21. [CrossRef] [PubMed]

11. Sportiello, L.; Cammarota, S.; de Portu, S.; Sautebin, L. Notification of undesirable effects of cosmetics and toiletries. Pharmacol. Res. 2009, 59, 101-106. [CrossRef]

12. Sautebin, L. A cosmetovigilance survey in Europe. Pharmacol. Res. 2007, 55, 455-460. [CrossRef]

13. Salverda, J.G.; Bragt, P.J.; de Wit-Bos, L.; Rustemeyer, T.; Coenraads, P.J.; Tupker, R.A.; Kunkeler, L.C.; Stenveld, H.J.; Kooi, M.W.; Bourgeois, F.C.; et al. Results of a cosmetovigilance survey in The Netherlands. Contact Dermat. 2013, 68, 139-148. [CrossRef] [PubMed]

14. Dhavalshankh, A.; Dhavalshankh, G. Cosmetovigilance:the study of prevalence \& vigilance of adverse cutaneous reactions in hairdye users. Int. J. Biol. Med Res. 2020, 3, 1704-1707.

15. Elmarzugi, N.A.; Keleb, E.I.; Mohamed, A.T.; El, H.A. Face powder problems perception survey. Int. J. Pharm. Sci. Invent. 2013, 2, 9-18.

16. Junaid, A.B.; Nasreen, R.; Ahmed, F. A study on the purchase behavior and cosmetic consumption pattern among young females in Delhi and NCR. J. Soc. Dev. Sci. 2013, 4, 205-211. [CrossRef]

17. Lindberg, M.; Tammela, M.; Boström, Å.; Fischer, T.; Inerot, A.; Sundberg, K.; Berne, B. Are adverse skin reactions to cosmetics underestimated in the clinical assessment of contact dermatitis? A Prospective Study among 1075 Patients Attending Swedish Patch Test Clinics. Acta Derm.-Venereol. 2004, 84, 291-295. [CrossRef] [PubMed] 
18. Maneesriwongul, W.; Dixon, J.K. Instrument translation process: A methods review. J. Adv. Nurs. 2004, 48, 175-186. [CrossRef] [PubMed]

19. Harkness, J.A.; Schoua-Glusberg, A. Questionnaires in translation. ZUMA-Nachr. Spezial 1998, 3, 87-127.

20. Population Distribution and Basic Demographic Characteristic Report. Department of Statistics Malaysia, 2010. Available online: https://www.statistics.gov.my/index.php?r=column/ctheme\&menu_ id=L0pheU43NWJwRWVSZklWdzQ4TlhUUT09\&bul_id=MDMxdHZjWTk1SjFzTzNkRXYzcVZjdz09 (accessed on 24 July 2016).

21. Kumar, R. Research Methodology: A Step-by-Step Guide for Beginners; SAGE Publications: London, UK, 2011.

22. Sadler, G.R.; Lee, H.C.; Lim, R.S.H.; Fullerton, J. Recruitment of hard-to-reach population subgroups via adaptations of the snowball sampling strategy. Nurs. Health Sci. 2010, 12, 369-374. [CrossRef] [PubMed]

23. Baltar, F.; Brunet, I. Social research 2.0: Virtual snowball sampling method using Facebook. Internet Res. 2012, 22, 57-74. [CrossRef]

24. Etcoff, N.L. Survival of the Prettiest: The Science of Beauty; Doubleday: New York, NY, USA, 1999.

25. Johansen, J.D. Fragrance contact allergy. Am. J. Clin. Dermatol. 2003, 4, 789-798. [CrossRef] [PubMed]

26. Truchliński, J.; Sembratowicz, I.; Gorzel, M.; Kiełtyka-Dadasiewicz, A. Allergenic potential of cosmetic ingredients. Arch. Physiother. Glob. Res. 2015, 19, 7-15. [CrossRef]

27. Groot, A.; Nater, J.; Lender, R.; Rijcken, B. Adverse effects of cosmetics and toiletries: A retrospective study in the general population. Int. J. Cosmet. Sci. 1987, 9, 255-259. [CrossRef]

28. Orton, D.I.; Wilkinson, J.D. Cosmetic allergy. Am. J. Clin. Dermatol. 2004, 5, 327-337. [CrossRef] [PubMed]

29. McFadden, J.P.; White, I.R.; Frosch, P.J.; Sosted, H.; Johansen, J.D.; Menne, T. Allergy Hair Dye. BMJ Br. Med J. 2007, 334, 220. [CrossRef] [PubMed]

30. Søsted, H. Allergic contact cermatitis to hair dye ingredients. Dan. Med. Bull. 2007, 54, 77.

31. Mansor, N.; Ali, D.E.B.M.; Yaacob, M.R. Cosmetic usage in Malaysia: Understanding of the major determinants affecting the users. Int. J. Bus. Soc. Sci. 2010, 1, 273-281.

32. Sautebin, L. Understanding the adverse effects of cosmetics. Drug Saf. 2008, 31, 433-436. [CrossRef] [PubMed]

33. Siti Zulaikha, R.; Norkhadijah, S.; Praveena, S. Hazardous ingredients in cosmetics and personal care products and health concern: A review. Public Health Res. 2015, 5, 7-15.

34. Kompaore, F.; Marty, J.; Dupont, C. In vivo evaluation of the stratum corneum barrier function in blacks, Caucasians and Asians with two noninvasive methods. Skin Pharmacol. 1993, 6, 200-207. [CrossRef] [PubMed]

35. Muizzuddin, N.; Hellemans, L.; Van Overloop, L.; Corstjens, H.; Declercq, L.; Maes, D. Structural and functional differences in barrier properties of African American, Caucasian and East Asian skin. J. Dermatol. Sci. 2010, 59, 123-128. [CrossRef] [PubMed]

36. Willis, C.M.; Shaw, S.; De Lacharriere, O.; Baverel, M.; Reiche, L.; Jourdain, R.; Bastien, P.; Wilkinson, J.D. Sensitive skin: An epidemiological study. Br. J. Dermatol. 2001, 145, 258-263. [CrossRef] [PubMed]

37. Graham, J.A.; Kligman, A.M. Physical attractiveness, cosmetic use and self-perception in the elderly. Int. J. Cosmet. Sci. 1985, 7, 85-97. [CrossRef] [PubMed]

(C) 2020 by the authors. Licensee MDPI, Basel, Switzerland. This article is an open access article distributed under the terms and conditions of the Creative Commons Attribution (CC BY) license (http://creativecommons.org/licenses/by/4.0/). 